\title{
The changing governance of welfare: revisiting Jessop's framework in the context of healthcare
}

\author{
Ian Greener ${ }^{1}$
}

Published online: 27 July 2020

(c) Springer Nature Limited 2020

\begin{abstract}
This paper revisits Jessop's governance of welfare framework, suggesting that in the post-financial crisis era of austerity we need to look again at its analytical dimensions. The paper reformulates Jessop's Schumpeterian Welfare Postnational Regime ideal-type framework through critique, and then applies its reformulated Galbrathian, Affluent Postnational Oligarchy ideal-type to the case of the English NHS to present a new political economy of health.
\end{abstract}

Keywords Jessop $\cdot$ Governance $\cdot$ Welfare $\cdot$ Political economy $\cdot$ NHS

\section{Introduction}

Jessop's work examining the changing governance of welfare (Jessop 1992, 1993, $1994,1999,2002$ ) is a hugely important contribution to a range of academic fields, ranging from politics and public policy through to social policy. In its social policy form (Jessop 1994, 1999), Jessop's work provides a key framework which research attempting to navigate the changing context of capitalism must navigate.

Jessop's contribution is to show how the governance of welfare has changed within an explanatory theoretical framework. He shows us not only where the current spatio-temporal fix of welfare governance has come from and where it is now, but also offers crucial clues as to where it might be going. This is bold and ambitious, as well as theoretically rigorous, work. In its final form, Jessop suggested that the governance of welfare, in ideal-type form (with the caveats this offers), should explore economic governance, social policy, and the predominant scale and mode of governance as well as the inter-relationships between each of those four dimensions. He suggested that this led to an analysis of the Anglo-American capitalism moving from being based on a Keynesian Welfare National State to a Schumpeterian Workfare Postnational Regime. Both ideal-type, spatio-temporal fixes come with their

Ian Greener

ian.greener@strath.ac.uk

1 University of Strathclyde, Glasgow, UK 
own tensions and contradictions because of the contradictions of capitalism itself (Offe 1984).

It is now some time since the fullest formulation of Jessop's framework, which appeared in his 2002 book The Capitalist State (Jessop 2002). But much has happened since then. In particular, we have had an economic crisis of a severity not seen since the 1930s, a governmental response to that crisis, a post-crisis era of policymaking in which 'austerity' has become a dominant theme, and most recently the worldwide COVID-19 pandemic. This paper critically re-examines Jessop's framework within the light of events after 2002, updating the framework and then applying it to a specific case - that of health policy — an area which previous work using the framework has examined (Greener 2004a, b) and which Jessop notes as being especially important in terms of future work to be developed (Jessop 2002, p. 152). Before then, however, it explores existing accounts of the governance of healthcare so that the paper can make clear its additional contribution to them.

\section{The changing governance of healthcare}

The political economy of health and healthcare has an extensive established literature far too broad to present beyond a brief review here. Highlights include Marxist theorising on the formation of the NHS (Navarro 1978), the dynamics of class and gender relations (Doyal 1979), and comparative studies of state-medico relations (Moran 1999). More recently Bambra's excellent work especially has integrated understandings from the literature on the social determinants of health to highlight the failure of governments of all colours in addressing health inequalities (Bambra 2017; Schrecker and Bambra 2015), and Scambler (2015) presents a reflective and theory-driven sociological critique of health inequalities, stigma, and their effects in fragmenting society.

When exploring a specific case study of the political economy of health, the NHS is a strong candidate for considering how such an integrative account of the political economy of welfare and of health can be constructed for two reasons. First, because as we noted above, Jessop himself suggests that healthcare is an important area which was under-explored in his examination of the changing governance of welfare. Second, because as we noted above existing work has utilised Jessop's framework to examine the NHS, this gives us a basis from which to offer a comparison and critique. It is to Jessop's framework that we now turn, incorporating in each dimension our critique and new interpretation.

\section{The governance of welfare}

Jessop's framework for the governance of welfare explores it in terms of four dimensions based on economic governance, social policy, and the scale and mode of governance. He suggests that spatio-temporal fixes appear under capitalism which supports different accumulation regimes in different periods. Understanding each of these dimensions and their inter-relationships is therefore crucial in understanding 
the formation of welfare, and as we will see later, the governance of healthcare. However, by revisiting Jessop's framework we can look again at this analysis, coming to a range of different conclusions and new insights.

\section{Economic governance}

The first dimension of governance explored in Jessop's framework is that of economic governance, and although often analysed separately from healthcare, has profound consequences for health policy. Jessop's framework suggests that economic governance has seen a shift from an ideal type of Keynesianism to one of Schumpeterianism. The perceived failure of Keynesianism in the 1970s and the rise of globalisation that resulted from economic liberalisation and changes in technology especially led to a shift in emphasis to the state becoming focused on achieving international competitiveness in an era of globalisation.

This narrative fits with most of the standard accounts of economic policy change since the 1960s (Hall 1986). Jessop is entirely correct in highlighting the increased flexibilisation of the labour market as becoming a government imperative, with labour costs becoming a cost of production rather than a source of demand for the economy (Krugman 2008). Prior to the financial crisis, an uneasy truce between government and the financial services industry had been reached in which the former were offered deregulation and tax breaks in return for the banks supporting government programmes to support welfare services through their payment of taxation-albeit often on highly preferential terms (Richards 2010).

Jessop's first governance change-from Keynesian to Schumpeterian economic governance-was reflected in healthcare as governments came to depend upon market mechanisms and quasi-markets as the common-sense of policymaking, and fits with the rise of the use of such mechanisms. These changes placed competition at the heart of healthcare governance, in line with a Schumpeterian approach that aimed to harness market forces to generate improvements and which treats labour as a cost of production rather than as a potential source of demand, as it is under a Keynesian approach.

However, Jessop's concern with competition driving a new ideal type of economic governance now appears to be challengeable from the perspective of the post-financial-crisis period. A singular cause of the crisis was the returns from investing in capital markets becoming substantially higher than those which were available in more conventional areas of the economy, creating serious imbalances between investment and speculative finance (Picketty 2014). The extraordinary losses incurred by the banks after 2007/2008 exposed their often illusory profits of the previous decade (Engelend et al. 2011), but this has not led to a 'rebalancing' of the economy to the non-financial sector. Rather than investing in the non-financial economy, the government continued to support the financial services industry through massive state-led interventions ranging from the outright ownership of banks regarded as having incurred such losses as to be unviable, through to quantitative easing, involving effectively exchanging non-liquid assets which have little or no resale value, for central bank funds (Stiglitz 2015). 
That the financial services industry ended up requiring such extraordinary state support to avoid systemic failure appears to have completely removed its legitimacy as being a highly competitive area of the economy - and casts doubt upon its claims the paradigm case of the knowledge-based economy in a globalised world. Instead, the financial services industry was deemed 'too big to fail' (Sorkin 2010), and was insulated against the competitive losses it had incurred. In 2007 and 2008, policymakers instead behaved more in line with the work of J.K. Galbraith than with Jessop's ideal-type selection, Schumpeter.

Galbraith, sceptical of what he called the 'conventional wisdom' of his discipline (Galbraith 1958), suggested that economics was still in thrall to a model borne of scarcity which no longer described the majority of economic activity. The main tendency which Galbraith suggested was unexplored in mainstream economics was the rise in corporate power (Galbraith 1975). This shift, he suggested, was profound as it not only insulated large firms from market pressures because of their sheer size, with oligopolistic and monopolistic forms becoming more common as firm size increased, but it also led to corporations being able to lobby government, and through the increased intermeshing of corporate and governmental interest, to become a significant driver of policy.

Along with this rise in corporate power, Galbraith also suggested that a focus on private sector consumption as the means of driving the economy was becoming the norm, in which, as economies became more affluent, the main aim of corporations was not the satisfaction of human need, but instead its manufacture. Rather than corporations being in thrall to the disciplines of the market, they were instead central to the constitution of consumer need, and not the passive respondents to demand they appear to be within conventional economy theory. It is hard not to see all the echoes of Galbraith's prescient warnings in the state of the economy today, especially with respect of financial services and corporate dominance, but also, as we will see, in respect of healthcare.

To be clear, this is not what Galbraith advocated as how we should be running our economies — in fact the opposite (Galbraith 1996) - but what has happened in the 2000s and 2010s most clearly shows the tendencies he saw as far back as the 1950s were coming to a head. These changes suggest that, rather than economic governance becoming more 'Schumpeterian', as in Jessop's original framework, it is instead going along the lines that Galbraith feared-and so should perhaps be considered 'Galbraithian' instead. This shift in governance has significant implications for healthcare.

\section{Galbrathian economic governance and healthcare}

While fully accepting the increased role for private organisations in the health services of England, the term 'Schumpeterianism' does not conceptually capture what has happened. A Galbrathian analysis instead places a focus on the role of corporations in the delivery of healthcare, and appears across a number of dimensions. 


\section{Complex patterns of ownership and conflicts of interest}

In 2003, the New Labour government put in place legislation creating greater scope for joint ventures which gathered momentum after the NHS reorganisation begun under the Coalition government of 2010, and have seen the increased involvement in non-public organisations in the delivery of care. Many of these organisations are multinational corporations which operate across geographic boundaries. The Hospital Corporation of America (HCA) is one of the world's largest private healthcare companies and caters for around half of all private patients in London (Competition Commission 2013) as well as having NHS joint ventures with hospitals in London, Romford, and Manchester. The introduction of organisations such as this into the NHS appears to have little to do with increasing competition, and more with creating opportunities for corporate rents. A central reason for concern about the entry of corporations such as HCA is that such corporations can threaten to withdraw from contracts, as did Circle at Hinchingbrooke hospital in 2015, should they find the terms of such contracts no longer suit them. This leaves the public sector left to pick up care contracts which it might have previously lost through the competitive tendering process - so that public bodies must retain the ability to provide comprehensive care, while private contractors can cherry-pick areas of care which they wish to enter-and from which they appear to be able to exit without any significant penalty.

The second dimension that corporations bring to care provision is relationships between their corporations and the state. Senior figures from banks brought in to advise governments on how they could improve, both in terms of financial regulation and tax regimes, but also in other, apparently disconnected areas such as healthcare and education (Wanless 2002). The Secretary of State for Health responsible for the introduction of the 2010 reorganisation, Andrew Lansley, went on to work for US consultancy Bain and Company advising corporate clients on healthcare reforms (Syal and Hughes 2015). The Chair of the Health Select Committee at the time of Lansley's reorganisation, Stephen Dorrell (who was also Secretary of State for health in the 1990s), took up a position as a senior advisor with KPMG UK's healthcare and public sector practice in December 2014. The current Chief Executive of the NHS in England is Simon Stevens, who formerly held a range of roles in the US corporation United Health. It is hard not to see the 'revolving-door' developing between government and the healthcare industry as a factor in policymaking (Leys and Player 2011, Chap. 7).

A third dimension relates to the second, and comes through the conflicts of interest that result from complex patterns of ownership in healthcare. In England general practitioners are a key part of the system that commissions (purchases) care, but there are continual concerns about conflicts of interest coming through GP ownership of practices that may also be receiving contracts (National Audit Office 2015). Complex ethical issues are arising in NHS hospitals which have created the category of 'self-funding patients', or patients who pay directly for NHS care in NHS facilities but to directly access treatments for which there are long waiting lists (Davis et al. 2015, Chap. 9). Regulators appear to struggle to oversee the complex patterns of ownership and the arising issues that result from mixed economies of different providers of care (Robertson 2015). 
A fourth dimension of the corporate dominance of healthcare comes through the role of the pharmaceutical industry. It is certainly the case that healthcare and the pharmaceutical industry are in a relationship of mutual need-healthcare needs the drugs that the industry provides and develops. However, there also seems to be a considerable amount of evidence that the industry has been able to engage in a variety of practices, perhaps most clearly documented by Goldacre (2013), where it has not released key research showing the efficacy of its drugs (or often, the lack of it), and not divulged data showing significant side effects. It also appears that the marketing budgets of large pharmaceutical firms are reaching levels that are near, or exceed, their research budgets, as they market aggressively to healthcare providers. That these arrangements have been allowed to persist for so long is an indication of the ability of the industry's ability to lobby policymakers and prevent change.

\section{The private finance initiative (PFI)}

Many of the above points combine in the Private Finance Initiative. PFI deals are meant to be about risk transfer (Asenova and Beck 2003). Schumpeterian creative destruction is about such deals being allowed to reach their outcomes, and both sides taking losses. But government intervention to protect the private sector from losses in PFI deals prevents that from happening, often in a context where the private sector is receiving extraordinary returns (Shaoul et al. 2008). In 2012, during the passage of the controversial Health and Social Care Bill through Parliament, and during a time when benefits were being cut, hospital trusts were offered a $£ 1$.5bn emergency fund in order to be able to continue paying for their PFI deals, with most of these funds going directly to their private sector partners (Campbell 2012). As such, while it is true that the state can repatriate authority at any point (Jessop 2015, pp. 204-205), its willingness to invest vast sums of public money to bail out deals with the private sector makes clear its underlying priorities when it does so.

The increased corporate influence over healthcare raises a range of concerns over vested interests coming to dominate policymaking, and of policymakers accessing to lucrative consultancies after they have left government. This does not look a lot like the 'creative destruction' of a competitive market system, but instead one where corporate influence is significantly increasing.

\section{Social policy}

Within social policy, Jessop suggests a move from welfare to workfare has occurred, defined in terms of social policy becoming subordinated to economic policy, and with the latter being primarily concerned with functioning as a globalised, competitive environment. This has resulted in a downward pressure on the 'social wage' and an attack on both worker and welfare rights - a strategy of 'flexploitation' (Viebrock and Clasen 2009). In Jessop's narrative, this involves labour moving from being regarded as a component of aggregate demand under Keynesianism, to being repositioned as a cost to industry. Social policy, however, 
is not only about the labour market as it can appear to be in Jessop's framework. At the same time as this, his use of 'workfare' is a little unclear, perhaps sometimes obscuring his intended meaning.

Accepting the changes Jessop outlines, but also acknowledging the need for a more clear concept, leads us to the concept of 'affluence'. In Galbraith's formulation, the 'affluent society' was one in which concern for inequality was declining and production became the foremost concern in economies (and economics), with the private sector regarded as being the source of economic growth and the driver of the economy. Public services, in contrast, were viewed as productivity laggards and drains on the productive economy (Galbraith 1958).

The governmental focus on private sector growth legitimates rising incomes and wealth inequalities which are seen as a natural function of the working of the free market, while affluence leads to an under-investment in the public services that are necessary to support private sector growth. This results in, to use one of Galbraith's many memorable phrases, 'private affluence and public squalor', as on average we become richer despite growing inequalities in income and wealth, while at the same time public services are systemically under-funded. These problems are not new, but have increased salience in an era where cuts in welfare services after the financial crisis have led to the majority of the burden in reducing the budget deficit resulting from the massive financial bailout of the banks in 2008, falling on the poorest (Hood and Johnson 2016). At the same time as this, it seems that the scope of the richest individuals and corporations to reduce their tax burden, or even avoid tax altogether, has reached extraordinary proportions (Treanor 2016).

There has also been an increase in hostility to paying taxation more generally. Living standards for the poorest have generally remaining static for a large proportion of those working in manual jobs or who are unemployed, leading to a distrust of politicians for those groups (Standing 2014). Reduced budget settlements, especially post 2008 , have led to public services struggling to maintain service standards, which in turn result in further increased dissatisfaction with them (Ipsos MORI 2015). The NHS has had its budgets more protected than other public services, but much smaller increases after 2010 appear to be associated with a stall in the progress made in a range of health indicators in the previous decade (Greener 2018). The combination of austerity and reduced standards of public provision has led to further hostility to paying increased taxation-while at the same time those who had the most before the financial crisis have come out losing least after it (Hood and Johnson 2016). We therefore end up with private affluence (for the richest) - but increased inequality, and public services struggling to deal with the demands upon them.

The resistance to taxation is part of what Taylor-Gooby (2013) has termed the 'double crisis' of the welfare state in which harsh spending cuts aimed especially at benefits and services for women, children, low-paid people, and claimants of working age, while at the same time undergoing a restructuring programme which is fragmenting services and embedding private provision. This leads to a combination of blaming the poor (and sometimes even the sick and disabled) for their need for benefits, and using that as a means of arguing that the public delivery of welfare services is failing or is unaffordable. 
There is something of a paradox around affluence-that on average we are growing richer, but within that average, inequalities are growing, and a range of research suggests this leads to a decline in trust and well-being for us all (Wilkinson and Pickett 2010). The central problem of confronting affluence is that those with the most income and wealth lobby hardest to retain their economic and social positions, while at the same time having the most resources and the best access to policymakers to do that lobbying.

\section{Health policy and affluence}

Health policy is affected by many of the points raised above-of reduced public settlements, increased inequalities, and increased disaffection with public services as the NHS appears to be in continual crisis. Meanwhile policymakers claim that budget rises would be unsustainable despite healthcare in the UK having one of the lower spends as a proportion of GDP in the OECD (Greener 2018). Healthcare affluence is justified as it is based on the idea that we make our own choice about health and lifestyle, with richest simply making better choices. But such a view does not explain the significant public health challenges we are facing, while at the same time legitimating public resistance to taxation and justifying health consumerism in its most basic forms.

Affluence justifies the rise in food bank use and homelessness as the inevitable result of competition in our society. At the same time, the most modern form of capitalism brings new health risks, most obviously in obesity and diabetes. But a large part of the problem with obesity comes through poor diets, and these, in turn, are related to the way the food industry has increasingly focused on the manufacture of consumer need for sugar, salt, and fat (Lustig 2014), while at the same time government subsidy, through accident or not, has led to large amounts of sugar being 'concealed' in a variety of foods where we might not expect it (Moss 2014). An entire industry exists to try and drive demand for a range of foods that have little in terms of nutritional value (linking to the discussion on Galbrathian corporate dominance above), but which are justified on the grounds that consumers choose them to eat them. Government has depended largely on self-regulation from the corporate food manufacturers and suppliers, and only recently begun to challenge the industry in a limited range of products, such as the sugar content of carbonated drinks, and even then the industry has threatened legal action against governments wishing to legislate against their products (Ruddick 2016).

At the same time as providing an argument against food industry regulation in the name of consumer choice, the discourse of affluence, as we noted above, legitimises resistance to taxation-on the basis that individuals, not governments, are bestplaced to make choices about what is best for them. Presenting individuals as sovereign decision-makers and consumers with no obligations to others suggests that we personally know what is best for us in terms of our own diet and exercise. But this argument, again, occurs in the face of the rising public health crisis that industrial countries are facing that seems to suggest we are rather more in thrall to corporate marketing than we might wish, even at the risk of our own health. 
We must also consider the demonisation of the poor in discourses of welfare more generally in any account of affluence, and in particular the success of government in stigmatising and othering benefit recipients so that it becomes acceptable for their health to be sacrificed should the economy as a whole be improved as a result (Bambra 2011; Garthwaite 2011; Schrecker and Bambra 2015). As such, while the notion of workfare clearly explains the subordination of health policy to corporate interests in the name of improving the economy, linking this to affluence gives us increased grip because of its challenging of the idea of health as a consumer good, and of the implications of that shift.

\section{The scale of governance}

Jessop suggested that the dominant scale of welfare governance has moved from the national (which worked alongside Keynesian economic policy in that it requires an active fiscal policy at least partially insulated from international capital markets), to the postnational scale as new loyalties came into play locally, and with supranational bodies as the EU exerting an increased influence, along with the growth of international capital and transnational organisations which escape national jurisdictions.

Jessop made clear that the movement towards the postnational scale left the state still as a major player, but risked it being decentred from analysis by his labelling. It is certainly the case that the nation state has struggled to deal with increased governance complexity, especially in the face of increased international capital flows challenging its economic jurisdiction, and immigration and increasing cultural diversity challenging ideas about nationhood. The challenges of environmental change and immigration have become writ large in national elections even though many of those issues are created beyond national borders. At the same time, in times of crisis, the national scale became hugely important. In the 2008 economic crisis, governments were required to take on substantial debts to prevent the collapse of the financial systems, and in 2020 the challenge of COVID-19 led to state-led impositions of curfew not seen since wartime. Jessop's labelling of the scale dimension as 'postnational' appears appropriate, even if it is the national state that is left trying to deal with many of the challenges that have resulted. Postnationalism has major implications for health policy.

\section{Postnationalism and health policy}

The most visible manifestation of the postnational aspect of healthcare has come through the increased involvement of multinational providers in the provision of healthcare in England especially. In this sense, healthcare has become more postnational. However, the shift to a postnational scale of governance highlights two additional effects of particular importance. First, there is tendency for central government to pass responsibility to the local level for the delivery of services. This was perhaps clearest in the first version of the 2010 NHS reorganisation when the 
Secretary of State attempted to pass responsibility for the delivery of health services entirely away from their role on the grounds it would 'liberate' and 'depoliticise' health services (Secretary of State for Health 2010). Harrison (2002), although his work pre-dates that reorganisation, captures the tension present in this most clearly in his analysis of 'scientific-bureaucratic' medicine, which seeks to routinise medical practice under the claim of evidence-based medicine, and then hold doctors to account for the delivery of the standardised form in an instrumental manner. Moves to 'depoliticise' care often present its delivery as a purely technical exercise when key questions about the levels of resource the state makes available, and what priorities are demanded in return for any increases, remain firmly within the remit of government.

Second, there is the increased role of international treaties in the governance of health. The negotiations over the Transatlantic Trade and Investment Partnership (TTIP) have stalled, and would now not apply to the UK post-Brexit, but TTIP still sets the context for discussions around US/UK trade relations. The main concern, not helped by the secrecy surrounding the treaty's negotiation, was that the treaty would be used to either open competition in the NHS further to American healthcare corporations, on the grounds that to resist such a change would be anti-competitive. This fitted the discourse of Schumpeterianism on the surface level-justifying change on the grounds it will create greater competition. But as the competition here would be primarily from large, multinational corporations, then this casts such competition in a very different light, adding to the suspicion it will be more Galbrathian as described above. In the context of the NHS, the debate around the corporatisation of healthcare comes even more clearly to the fore.

Finally, postnational challenges to health and healthcare are becoming clearer to us, but require international levels of co-operation which seem beyond our current governance systems. Environmental change requires us to curb economic growth and invest in greener technologies, but our national-based governments are struggling (at best) to rise to this challenge, especially in the face of populist politicians appealing directly to industries threatened by such change, especially in the United States and Australia (Baer 2016).

The spread of COVID-19 in 2020 presented governments with the decision of deciding when to effectively close down their economies and invest in their national health systems to support seriously ill people of all social backgrounds. Governments were presented with a stark choice between the good of the economy and minimising death amongst those falling ill, and led to them quickly finding funds to support health system which would have been routinely labelled as 'unaffordable' weeks before. This rapid change in approach highlighted the extent to which decisions about what kinds of healthcare we can and cannot afford are deeply political, as well as leaving us wondering whether the response would have been as fulsome had the virus not threatened the entire population, and fallen instead predominantly on groups the same governments had previously stigmatised. At the time of writing (early June 2020), England has amongst the highest death rates in the world from COVID, with the most vulnerable being especially affected after 10 years of austerity government (Duneavy 2020). 


\section{Predominant mode of governance}

Finally, in terms of the mode of governance, Jessop argues that the post-war period has seen a shift from one which was dominated by state-based provision to one which takes a regime form instead-involving a variety of different providers from different sectors of the economy.

Regime-based governance is apparent in relation to healthcare, through a proliferation of care providers that have sprung up in relation to market incentives, covering public, not-for-profit, and private provision. Even in public hospitals, non-public providers of services for parking, television, food and drink are widespread, blurring the boundaries between the different sectors. However, at the same time as welfare governance has come under increased pressure, it is to the state which private organisations have increased turned secure tax breaks, subsidies, contracts, and other means of support. While welfare benefits have become more conditional across a range of areas, relatively little appears to be asked in return for the 'corporate welfare' that such organisations are receiving (Farnsworth 2013). This growth in corporate welfare leads us to asking whether governance is really based on a regime, and instead might be characterised in rather different terms.

'Oligarchy' is a term typically associated with feudal regimes of the past or with government systems where corruption is rife-in the contemporary world, the 'oligarchs' of post-Glasnost Russia being the clearest example. However, as both income and wealth inequalities increase in both the US and UK there is a point at which the power and influence of a small proportion of people becomes so significant that it beings to appear that government policy is being run on oligarchic terms. In the UK, the bottom $10 \%$ of the population have an average net income of $£ 8,468$ in 2016 , but the top $1 \%$ have a net income of $£ 259,917$ and the top $0.1 \%$ an average of $£ 941,582$ (The Equality Trust 2016). Half of the Cabinet elected in 2010 were privately educated (compared to $7 \%$ of the general population) and half also attended either Oxford or Cambridge University (Gurney-Read 2015) and examinations of who is governing on behalf of whom have pointed to an emerging oligarchy or, in Mount's (2013) memorable phrase, 'new few'. With reference to the US, Winters and Page (2009) suggest that it is already the case in some areas of policymaking that 'oligarchy' represents a term which is becoming appropriate (see also Winters 2011).

As such, there are clear tendencies appearing, and for us to consider the mode of governance showing tendencies to be governed and run for the benefit of the few.

\section{Oligarchy and health policy}

The oligarchic tendencies in healthcare are most visible in examining life expectancy and the major reasons for mortality across the social groups. A 2016 report shows the extent of this in the UK, suggesting that "measures such as healthy life 
expectancy and disability-free life expectancy vary significantly by region and social class' (Mahew and Smith 2016, p. 1). If we describe these differences as being the result of individually bad choices, as the authors of the report tend to, then they are perhaps easily presented as being related to affluence, and can be resolved by us educating people to make better decisions. But the richest in society appear to have better life expectancy and improved well-being in a way that goes beyond their lifestyle choices-in the language of Marmot (2015), the differences suggest something approaching social determinism. In Bambra's terms, it genuinely does appear that where you live can kill you prematurely (Bambra 2017).

We have already mentioned the food industry, but its centrality to the topic bears some repetition. The food industry is dominated by a small number of multinational corporations clearly shows an oligarchic structure, as well as reproducing class-differentiated relations. The poorest are structurally located in positions where the purchase of calorific, unhealthy food is made as straightforward as possible for a group already suffering from the greatest degree of cognitive scarcity, and so finding it difficult to make the 'right' choices public health specialists would advocate for them (Mullainathan and Shafir 2013).

The structural location of the poorest is made most clear by the work of Marmot, who suggests our health does not, as economists might suggest, determine our job and social class as a factor of production through labour, but instead that our social position determines our health (Marmot 2012, 2015). Marmot shows that countries with the lowest levels of inequality also have, on average, the highest levels of life expectancy-suggesting that it is genuinely in all our interests to seek a more equal society. The levels of inequality in our economies are not a natural feature-they are the result of government policy, and subject to change-indeed Marmot's examples include countries where reducing inequalities has resulted in increased levels of life expectancy across the different social groups of that country (Marmot 2015, Chap. 9). The emphasis on flexible labour markets and the growth of the 'platform' and 'gig' economies in the UK and US have created complex work contexts which can act even greater pressures on the most insecure, and which will surely come with health implications (Bajwa et al. 2018).

However, even though everyone appears to gain in terms of health outcomes from reduced inequality, the richest have, arguably, gain the least (at least in terms of their own outcomes) from a redistribution in income and wealth as they already have private health insurance and quicker access to care which will compensate them for any lifestyle challenges their unequal society may bring to them. As such, asking the richest to pay more tax or to take greater responsibility for other groups-especially when those other groups have been described by governments as feckless, is a difficult message to convey, and against which considerable resources are likely to be expended.

In Scambler and Scambler (2015)'s words 'It is Britain's governing oligarchy that most notably occasions, reproduces, underwrites and in today's financial capitalism intensifies its health inequalities' (p. 351). This is a stratified tragedy of the commons in which we all can gain from a more equal distribution of income and wealth, but this is prevented by an elite who justify their behaviour, even unconsciously, 
based on misleading claims of free choice in free markets to the exclusion of the morality and ethics of their actions (Smith 2015). The end result is oligarchic, and welfare governed by the few for their own benefit.

\section{Conclusion}

In organising a complex set of changes into a framework which can bring out its emergent tendencies, Jessop's contribution is an extraordinary one, and it deserves to be as widely-cited and influential as it is.

At the same time, however, the world has changed since 2002, and the effect of the economic crisis especially has been significant in both bringing out alreadyexisting tendencies, as well as revealing new ones. This paper aimed to examine Jessop's framework in the light of these changes, as well as to illustrate what difference a revised framework might make in exploring a specific case- that of healthcare.

The new framework presented here, the Galbraithian Affluent Postnational Oligarchy (GAPO), can make a case for better explaining the changed governance of welfare after 2007/8 than Jessop's SWPR ideal type. At very least it serves as an alternative to Jessop's original formulation in its greater inclusion of the role of corporate power and its questioning of the extent to which competition has become the driving motive of state policy. In Jessop's spatio-temporal fix, the tensions are between competition and postnationalism, with social policy being subordinated to economic policy. Those tensions are real, but starting with an assumption of global competition as a driving force is a significant error-starting with corporate dominance leads us to a very different interpretation and to tensions based around how we might challenge corporate interests in a time when the elites which dominate them have also come to exert such influence over social policy in serving their own ends.

Applying the GAPO framework to healthcare brings out a range of additional challenges that Jessop's SWPR does not show as forcefully-including the role of especially US multinational corporations in the delivery of healthcare in other countries, the importance of the private finance initiative in showing government priorities, and of a range of public health problems which are having real effects in terms of inequalities in lifespans.

The governance of welfare is clearly an area subject to further change. However, in conclusion, it does appear that, as an economist for our time, Galbraith is a more apposite figure than Schumpeter in describing the present context and explaining its tendencies and likely effects. The paper integrates many of the existing critiques of the political economy of health, showing them to be inter-linked in ways which do not always appear in the accounts separately. Corporate dominance is linked to health inequalities and to the dominance of policy by vested interests in ways we have not seen since the 1930s (Stiglitz 2012). Equally, work on the 'social determinants of health' is clearly located within the GAPO framework as being linked to such corporate dominance, but also to the underlying condition of Affluence that Galbraith outlined. Exploring these topics in a more inter-related way shows how 
they fit into a wider picture of the political economy of health, as well as creating the space for further work detailing how their relations work out in greater detail.

The GAPO framework also makes clear the tensions in the present spatio-temporal fix, but perhaps Galbraith himself made these most clear towards the end of this life. In The Culture of Contentment, Galbraith suggested that the 'present age of contentment will come to an end only when and if the adverse developments it fosters challenge the sense of comfortable well-being' (Galbraith 1993, pp. 156-157). He suggested that such an 'adverse development' might come from a political appeal from the disadvantaged, or that an economic disaster might also lead to a new approach - and it is to some extent ironic that the US and UK governments taking such a non-Schumpeterian approach after the financial crisis and bailing out the banks may have prevented such an economic disaster from occurring (Mirowski 2013). It remains to be seen in 2020 whether the outbreak of COVID-19 might yet lead to such a change. If it does not, we might remember the warning Galbraith issued, that there could come a point where the dispossessed rise up in protest against what is being done to them-against the 'fractured society' (Scambler 2015) that our financial and political elites have created. Perhaps there is a salutary lesson here-if inequalities continue to grow, and the poorest in our society continue to face most of the consequences of preserving affluence, not least in terms of their own health, there will surely come a reckoning where those in power will be forced to change their course.

\section{References}

Asenova, D., and M. Beck. 2003. The UK financial sector and risk management in PFI projects: A survey. Public Money and Management 23: 195-202.

Baer, H. 2016. The nexus of the coal industry and the state in Australia: Historica dimensions and contemporary challenges. Energy Policy 99: 194-202.

Bajwa, U., D. Gastaldo, E. Di Ruggiero, and L. Knorr. 2018. The health of workers in the global gig economy. Globalization and Health 14: 124.

Bambra, C. 2011. Work, worklessness, and the political economy of health. Oxford: Oxford University Press.

Bambra, C. 2017. Health divides: Where you live can kill you. Bristol: Policy Press.

Campbell, D. 2012. Hospital trusts offered $£ 1.5$ bn emergency fund to pay PFI bill. Guardian, 13th February.

Competition Commission. 2013. Private health in Central London: Horizonal competitive constraints. London: Competition Commission.

Davis, J., J. Lister, and D. Wrigely. 2015. NHS for sale: Myths, lies and deception. London: Merlin Press.

Doyal, L. 1979. The political economy of health. London: Pluto Press.

Duneavy, P. 2020. A modern 'Rasputin' or the UK's 'Vice-Premier': Whichever view you take, cummings's role is unprecedents. LSE British Politics and Policy Blog. https://blogs.lse.ac.uk/politicsan dpolicy/dominic-cummings-row/. Accessed 26 July 2020.

Engelend, E., I. Erturk, J. Froud, A. Nilson, and K. Williams. 2011. After the great complacence: Financial crisis and the politics of reform. Oxford: Oxford University Press.

Farnsworth, K. 2013. Bringing corporate welfare back in. Journal of Social Policy 42: 1-22.

Galbraith, J.K. 1958. The affluent society. London: Penguin.

Galbraith, J.K. 1975. The new industrial state. London: Pelican.

Galbraith, J.K. 1993. The culture of contentment. London: Penguin.

Galbraith, J.K. 1996. The good society: The humane agenda. London: Sinclair-Stevenson. 
Garthwaite, K. 2011. 'The language of shirkers and scroungers?' Talking about illness, disability and coalition welfare reform. Disability and Society 26: 369-372.

Goldacre, B. 2013. Bad pharma: How medicine is broken and how we can fix it. London: Fourth Estate.

Greener, I. 2004a. Health service organisation in the UK: A political economy approach. Public Administration 82: 657-676.

Greener, I. 2004b. The new political economy of the UK NHS. Critical Public Health 14: 239-250.

Greener, I. 2018. Learning from new Labour's approach to the NHS. In Social policy review, vol. 30, ed. C. Needham, E. Heins, and J. Rees. Bristol: Bristol University Press.

Gurney-Read, J. 2015. Half of the new Cabinet 'went to Oxbridge'. Telegraph, 11th May.

Hall, P. 1986. Governing the economy: The politics of state intervention in Britain and France. New York: Oxford University Press.

Harrison, S. 2002. New labour, modernisation and the medical labour process. Journal of Social Policy 31: $465-485$.

Hood, A., and P. Johnson. 2016. Are we 'all in this together'. London: Institute for Fiscal Studies.

Ipsos MORI. 2015. Coming to terms with austerity?. London: Ipsos MORI.

Jessop, B. 1992. Fordism and post-Fordism: A critical reformulation. In Pathways to industrialisation and regional development, ed. M. Storper and A. Scott. London: Routledge.

Jessop, B. 1993. Towards a schumpeterian workfare state? Preliminary remarks on post-fordist political economy. Studies in Political Economy 40: 7-39.

Jessop, B. 1994. The transition to post-Fordism and the Schumpeterian workfare state. In Towards a postfordist welfare state?, ed. R. Burrows and B. Loader, 13-37. London: Routledge.

Jessop, B. 1999. The changing governance of welfare: Recent trends in its primary functions, scale and modes of coordination. Social Policy and Administration 33: 348-359.

Jessop, B. 2002. The future of the capitalist state. Cambridge: Polity Press.

Jessop, B. 2015. The state: Past, present, future. Cambridge: Polity Press.

Krugman, P. 2008. The return of depression economics and the crisis of 2008. London: Penguin.

Leys, C., and S. Player. 2011. The plot against the NHS. Pontypool: Merlin Press.

Lustig, R. 2014. Fat chance: The hidden truth about sugar, obesity and disease. London: Fourth Estate.

Mahew, L., and D. Smith. 2016. An investigation into inequalities in adult lifespan. London: Cass Business School.

Marmot, M. 2012. Status syndrome: How your social standing directly affects your health. London: Bloomsbury.

Marmot, M. 2015. The health gap: The challenge of an unequal world. London: Bloomsbury.

Mirowski, P. 2013. Never let a serious crisis go to waste: How neoliberalism survived the financial meltdown. London: Verso.

Moran, M. 1999. Governing the healthcare state: A comparative study of the United Kingdom, the United States and Germany. Manchester: Manchester University Press.

Moss, M. 2014. Fat, sugar, salt: How the food industry hooked us. London: WH Allen.

Mount, F. 2013. The new few: Or a very british oligarchy. London: Simon and Schuster.

Mullainathan, S., and E. Shafir. 2013. Scarcity: Why having so little means so much. London: Penguin.

National Audit Office. 2015. Managing conflict of interest in NHS clinical commissioning groups. London: National Audit Office.

Navarro, V. 1978. Class struggle, the state and medicine. New York: Prodist.

Offe, C. 1984. Contraditions of the welfare state. London: Hutchinson.

Picketty, T. 2014. Capital in the twenty-first century. Cambridge, MA: Harvard University Press.

Richards, S. 2010. Whatever it takes: The real story of gordon brown and new labour. London: Fourth Estate.

Robertson, R. 2015. Should we be worried about CCG conflicts of interest?. London: The King's Fund.

Ruddick G. 2016. Drinkers makers consider legal action against sugar tax. Guardian, 20th March.

Scambler, G. 2015. Sociology, health and the fractured society: A critical realist account. London: Routledge.

Scambler, G., and S. Scambler. 2015. Theorizing health inequalities: The untapped potential of dialectical critical realism. Social Theory and Health 13: 340-354.

Schrecker, T., and C. Bambra. 2015. How politics makes us sick: Neoliberal epidemics. Basingstoke: Palgrave Macmillan.

Secretary of State for Health. 2010. Equity and excellence: Liberating the NHS. London: The Stationary Office Limited. 
Shaoul, J., A. Stafford, and P. Stapleton. 2008. The cost of using private finance to build, finance and operate hospitals. Public Money \& Management 28: 101-108.

Smith, K. 2015. Understanding responses to the political context of health inequalities in research and policy: Can post-structural theories of power help? Social Theory and Health 13: 355-376.

Sorkin, A.R. 2010. Too big to fail: Inside the battle to save wall street. London: Penguin.

Standing, G. 2014. The precariat: The new dangerous class. London: Bloomsbury.

Stiglitz, J. 2012. The price of inequality. London: Penguin.

Stiglitz, J. 2015. The great divide. London: Penguin.

Syal, R., and S. Hughes. 2015. Ex-health secretary Andrew Lansley to advise firms on healthcare reforms. Guardian, 20th October.

Taylor-Gooby, P. 2013. The double crisis of the welfare state and what we can do about it. Basinstoke: Palgrave MacMillan.

The Equality Trust. 2016. The scale of economic inequality in the UK. https://www.equalitytrust.org.uk/ scale-economic-inequality-uk. Accessed 24 May 2016.

Treanor, J. 2016. US corporate giants hoarding more than a trillian dollars. Guardian, 20th Mary.

Viebrock, E., and J. Clasen. 2009. Flexicurity and welfare reform: A review. Socio-Economic Review 7: 305-331.

Wanless, D. 2002. Health care: The 20-year plan. Public Money \& Management 22: 4-5.

Wilkinson, R., and K. Pickett. 2010. The spirit level: Why equality is better for everyone. London: Penguin.

Winters, J. 2011. Oligarchy. Cambridge: Cambridge University Press.

Winters, J., and B. Page. 2009. Oligarchy in the United States? Perspectives on Politics 7: 731-751.

Publisher's Note Springer Nature remains neutral with regard to jurisdictional claims in published maps and institutional affiliations. 